\title{
Relationship between protein-energy malnutrition, vitamin A, and parasitoses in children living in Brasília
}

\author{
Relação entre desnutrição energético-protéica, vitamina A, \\ e parasitoses em crianças vivendo em Brasília
}

Maria Imaculada Muniz-Junqueira' ${ }^{1}$ and Eduardo Flávio Oliveira Queiróz ${ }^{2}$

\begin{abstract}
It is still controversial whether intestinal parasitic infections can influence the nutritional status of children. The relationship between protein-energy malnutrition, vitamin $A$ and parasitic infections was evaluated in 124 children. The food intake estimated by recall method was generally low and poor. Seventy five percent of the children were infected with intestinal parasites. The mean $\pm S D$ weight-for-age and height-for-age Z-score were skewed one standard deviation to the left, when compared to normal standards. An association was found between protein-energy malnutrition and Giardia lamblia, but not with Ascaris lumbricoides or Hymenolepis nana infection. Only Giardia-infected children had a decreased weight-for-age and weight-for-height Z-score. Hypovitaminosis $A$ was a major nutritional problem, but no relationship between this deficiency and parasitic infection was found. Our data indicate that low and poor food intake were the major cause of protein-energy malnutrition among the children, and except for Giardia, this was not influenced by parasitic infections.

Key-words: Protein energy-malnutrition. Vitamin A. Iron. Intestinal parasitic infection. Ascaris lumbricoides. Giardia lamblia. Hymenolepis nana.

Resumo É controverso se parasitismo intestinal interfere no estado nutricional. A relação entre desnutrição energético-protéica, vitamina A e parasitoses intestinais foi avaliada em 124 crianças. A ingestão alimentar estimada pelo método recordatório mostrou-se deficiente em quantidade e qualidade. Setenta e cinco porcento das crianças estavam parasitadas. $A$ média $\pm D P$ do Z-escore do peso-para-idade e altura-para-idade da população estudada desviou-se aproximadamente um DP para a esquerda em relação aos padrões normais. Encontrou-se associação entre desnutrição energético-protéica e parasitismo por Giardia lamblia, mas não por Ascaris lumbricoides ou Hymenolepis nana. Somente crianças infectadas por Giardia mostraram deficiência do peso-para-idade e peso-para-altura avaliado pelo Z-escore. Hipovitaminose A foi um importante problema nutricional, mas não houve relação entre esta deficiência e parasitoses intestinais. Nossos dados indicam que deficiência na quantidade e na qualidade da ingestão foram os principais problemas causando desnutriçãoenergético protéica, e exceto para Giardia, não foi influenciado pelo parasitismo por helmintos intestinais.
\end{abstract}

Palavras-chaves: Desnutrição energético-protéica. Vitamina A. Ferro. Parasitas intestinais. Ascaris lumbricoides. Hymenolepis nana. Giardia lamblia.

Protein-energy malnutrition and intestinal parasitic infections are common problems in those populations characterized by low socioeconomic status and low level of public health sanitation ${ }^{2}{ }^{36}$. Ascaris lumbricoides infection is often associated with malnutrition, but it is difficult to clarify whether the relationship is causative or casual, since both are ubiquitous in such conditions of poverty and poor sanitation².
Several data suggest that parasite infections can affect the nutritional status of infected people, by modifying the key stages of food intake, digestion and absorption $^{35}$. Parasites can adversely affect the host food intake by decreasing, increasing ${ }^{9}$ or changing the preference for food, as in patients with pica ${ }^{16}$. They can affect sensory, neural and hormonal factors that are considered to modulate food intake ${ }^{9}$, and can cause

\footnotetext{
1. Laboratório de Imunologia Celular, Área de Patologia, Faculdade de Medicina da Universidade de Brasília, Brasília, DF, Brasil. 2. Área de Medicina Social da Faculdade de Medicina, Universidade de Brasília, Brasília, DF, Brasil.

This study was supported in part by CNPq (National Research Council of Brazil), process number 40.5763/82 and 12.1634/83.

Address to: Dra. Maria Imaculada Muniz-Junqueira. Laboratório de Imunologia Celular, Área de Patologia/Faculdade de Medicina/UnB, 70910-900, Brasília, DF, Brazil.

Tel: 5561 307-2273; 5561 234-2159, Fax: 5561 233-0296

e-mail:Ifjjnq@embratel.net.br

Recebido para publicação em 5/3/2001.
} 
anorexia $^{1}$, or vomiting ${ }^{2}$. It was found that trophozoites of Giardia lamblia may damage the brush borders of enterocytes and impair the activity of mucosal enzymes, particularly the disaccharidases ${ }^{2}$, causing carbohydrate and fat malabsorption ${ }^{10}$. Abnormalities were observed in the intestinal tract mucosa in Ascaris lumbricoidesinfected children through jejunal biopsy ${ }^{39}$, which disappeared rather rapidly after deworming treatment, accompanying by the improvement of the nitrogen retention, d-xylose absorption and steatorrhea ${ }^{39}$. However, it is still controversial whether such alterations influence the nutritional status of children when tested in field studies. While some studies have shown a beneficial impact of antiparasitic treatment on the nutritional status and growth of children, others have not achieved the same results ${ }^{2022}$. It was observed that periodically deworming Ascaris lumbricoides-infected children may improve their nutritional status ${ }^{1843}$, and that a single course of antiparasitic treatment increased arm skinfold ${ }^{37}$ and improved growth ${ }^{38}$. Cerf et $\mathrm{al}^{7}$ showed a significant negative correlation between the burden of Ascaris and nutritional status, but exclusively in the population submitted to low nutritional intake and living in conditions of poor health care facilities. Moreover, periodic treatment of Giardia lamblia improved the weight gain of treated children ${ }^{18}$. On the other hand, Freij et $\mathrm{al}^{15}$ observed no impact on anthropometric indices after ascariasis treatment, Geengberg et $\mathrm{al}^{17}$ showed that a single dose of piperazine was an unsuccessful method to promoting growth, Gupta and Urrutia ${ }^{19}$ have not found any effect on nutritional status after deworming Ascaris lumbricoides-infected children for one year, and Kightlinger et $\mathrm{al}^{27}$ observed that children with the heaviest worm burdens had growth scores very similar to the lightly and non-infected ones. Thus, it is not yet clear whether parasites can influence the nutritional status of children. A major difficulty in interpreting these results is the fact that several parasites and nutritional deficiencies can coexist and influence each other. For instance, hypovitaminosis $A$, a problem of public health among young children living in areas of poverty that can led to blindness and death ${ }^{30}$, can be caused by impairment of vitamin A absorption due to Ascaris lumbricoides or Giardia lamblia infections ${ }^{28}$, while iron-deficiency anemia has been associated to infection by Ancylostomidae, Trichuris trichiura and Schistosoma mansoni ${ }^{3} 3134$.

In conditions of poverty and low level of sanitation when multiple deficiencies coexist, the consequences of interactions between multiple nutritional deficiencies and multiple intestinal parasites are not clear, and these associations have not yet been assessed in the same population. This work aimed to evaluate the relationship between protein-energy malnutrition, hypovitaminosis $A$ and intestinal parasitic infections in children living in poor social conditions in Brasilia.

\section{STUDY GROUPS AND METHODS}

All the 124 children, younger than 6 years old, of both sexes, living in Varjão, a slum area in Brasilia, Brazil, were evaluated for their nutritional status and presence of parasites in their stool in a cohort study performed in 1983. In this small community, the children were submitted to the same social, cultural, economic and environmental influences. The family incomes were similar, and in the area they lived there was no supply of treated water or public sanitation.

All the children were evaluated by a clinical examination. The weight, height and head circumference were measured using standard anthropometric measurement ${ }^{46}$ by the same observer (MIM-J). The nutritional status was evaluated by the standard deviation score (Z-score $)^{46}$, percentile ${ }^{46}$ and Waterlow classification ${ }^{41}$. The $50^{\text {th }}$ percentile of the growth charts of the National Center for Health Statistic (NCHS), USA, was used as normal standard ${ }^{21}$. Sixty-eight out of 124 children were younger than three years old and their head circumference was analyzed using the $50^{\text {th }}$ percentile from the NCHS chart ${ }^{21}$. The food intake was estimated for energy, protein, retinol and iron by the 24 hour-recall method for 104 children using the IBGE (Brazil) nutrient composition table ${ }^{23}$, and the FAO/WHO criteria for daily recommended intake ${ }^{121314}$. Dietary intake of carotenoid precursors and preformed vitamin A were computed together and expressed as retinol equivalent intake. Sixteen breast-fed babies receiving human milk together with supplementary food were excluded from the analysis. Therefore only the results of the intake of 88 children were considered.

The intestinal parasites were detected in the stools of 102 children using four different tests: sedimentation test of Hoffmann, Pons and Janer, Baermann test for larvae, Faust test for protozoa cysts ${ }^{32}$, and Kato-Kats test ${ }^{25}$. The latter was also used for calculating the burden of Ascaris lumbricoides. All stool samples were submitted to the four tests. The 24-hour samples of stools collected in a plastic bag were weighed. The number of Ascaris lumbricoides infecting each child was estimated by the number of eggs counted in $1 \mathrm{~g}$ of stool (detected by the Kato-Kats method), multiplied by the weight of the stools collected during 24 hours; divided by 200,000 (number of eggs expelled by each female Ascaris lumbricoides), multiplied by 2 (proportion between male and female of Ascaris lumbricoides), according to the equation proposed by $\mathrm{WHO}^{45}$ : number of parasites $=$ [(number of eggs per gram of stools $\mathrm{X}$ weight of stools from $24 \mathrm{~h}) / 200,000$ ] $\times 2$.

The presence of 5 or less parasites was considered as light infection, from 6 to 25 as moderate and over 25 worms as heavy infection ${ }^{45}$.

Samples of 2 to $5 \mathrm{ml}$ of peripheral venous blood were obtained and sera were kept at $-20^{\circ} \mathrm{C}$ until used. Levels of vitamin $A$ in serum from 122 children were evaluated in duplicate for individual sample by the colorimetric 
method employing the Carr Price reaction using trifluoroacetic acid (TCA) as a chromogen, and were expressed as $\mu \mathrm{g}$ of retinol per $100 \mathrm{ml}^{5}$. Hemoglobin was detected in duplicate samples of blood immediately after collection from 121 children by the cyanmethemoglobin method, and was expressed as $\mathrm{g}$ per $\mathrm{dL}$ of blood ${ }^{11}$.

The statements of the Helsinki Declaration ${ }^{44}$ and of the Health Ministry of Brazil for research in human subjects were strictly followed throughout this investigation. All children received $200,000 \mathrm{U}$ vitamin A per os and their parasite infections were treated as soon as they were detected.
Statistical analysis was performed by one way ANOVA and subsequent Student-Newman-Keuls multiple comparison when the samples showed a normal distribution, or by Kruskall-Wallis test followed by Dunn's method of multiple comparisons to compare nongaussian distributed samples. The Mann-Whitney test was performed to compare two non-gaussian distributed samples. Chi-square test was used to compare proportions. Correlation between variables was assessed by Spearman coefficient. All results with a p value $<0.05$ were considered statistically significant. The SigmaStat Jandel's statistical software (Jandel Scientific, San Rafael/ California, USA, 1992) was used for the analysis.

\section{RESULTS}

The mean weight-for-age and height-for-age Z-score of all children were skewed about one standard deviation to left in relation to $\mathrm{NCHS}$ reference standard, as shown in Table 1, while the mean weight-for-height was not different from that of the NCHS reference standard. There was no statistical difference in the mean Z-score between ages (Table 1).

Figure 1 shows the distribution of the population according to percentiles of anthropometric indices. The height-for-age showed the distribution skewed toward the lower percentiles, with $46 \%(57 / 124)$ of the children below the $10^{\text {th }}$ percentile, and $22.6 \%(28 / 124)$ below the $3^{\text {rd }}$ percentile (Figure 1A). The weight-for-age was also skewed toward lower values, with $30.6 \%$ (38/124) of the children below the $10^{\text {th }}$ percentile, and $12 \%(15 / 124)$ below the $3^{\text {rd }}$ percentile (Figure 1B). The weight-forheight showed a homogeneous arrangement with $7.3 \%$ $(9 / 124)$ below the $10^{\text {th }}$ percentile and $2.4 \%$ (3/124) below the $3^{\text {rd }}$ percentile (Figure 1C). The same skew toward the lower percentiles was observed in head circumference, with $61.8 \%(42 / 68)$ of the children below the $10^{\text {th }}$ and $47 \%(32 / 68)$ below the $3^{\text {rd }}$ percentile (Figure 1D). Application of the Waterlow classification showed that $8.9 \%(11 / 124)$ of the children were stunted.

Table 1 - Weight-for-age, height-for-age and weight-for-height Z-scores and serum retinol concentration according to age of children younger than 6 years old living in Varjão, a slum area in Brasilia, Brazil.

\begin{tabular}{|c|c|c|c|c|c|c|c|}
\hline \multicolumn{8}{|c|}{ Age (year) } \\
\hline & $<1$ & $1-2$ & $2-3$ & $3-4$ & $4-5$ & $5-6$ & Total \\
\hline \multicolumn{8}{|l|}{ Weight-for-age } \\
\hline $\mathrm{N}$ & 15 & 26 & 25 & 20 & 22 & 16 & 124 \\
\hline mean Z-score ${ }^{*}$ & -0.98 & -1.07 & -0.97 & -0.40 & -0.91 & -0.78 & -0.86 \\
\hline SD & 1.18 & 1.07 & 0.96 & 0.63 & 0.76 & 1.13 & 0.97 \\
\hline below -2 Z-scores (\%) & 20 & 11.5 & 12 & 0 & 4.5 & 12.5 & 9.7 \\
\hline \multicolumn{8}{|l|}{ Height-for-age } \\
\hline $\mathrm{N}$ & 15 & 26 & 25 & 20 & 22 & 16 & 124 \\
\hline mean Z-score* & -1.54 & -1.38 & -1.59 & -0.83 & -1.15 & -0.98 & -1.21 \\
\hline SD & 1.28 & 0.89 & 0.99 & 0.66 & 0.89 & 1.17 & 1.04 \\
\hline below -2 Z-scores (\%) & 40 & 19.2 & 24 & 5 & 18.1 & 12.5 & 19.4 \\
\hline \multicolumn{8}{|l|}{ Weight-for-height } \\
\hline $\mathrm{N}$ & 15 & 26 & 25 & 20 & 22 & 16 & 124 \\
\hline mean Z-score* & 0.21 & -0.37 & -0.16 & 0.35 & -0.17 & -0.21 & -0.09 \\
\hline SD & 0.74 & 0.86 & 0.94 & 0.81 & 0.71 & 0.89 & 0.85 \\
\hline below -2 Z-scores (\%) & 0 & 3.8 & 0 & 0 & 0 & 0 & 0.8 \\
\hline \multicolumn{8}{|l|}{ Retinol $(\mu \mathrm{g} / \mathrm{mL})$} \\
\hline $\mathrm{N}$ & 15 & 26 & 24 & 19 & 22 & 16 & 122 \\
\hline median $^{\star *}$ & 15.6 & 19.0 & 20.1 & 16.8 & 18.3 & 18.5 & 18.31 \\
\hline 25 percentile & 13.2 & 16.6 & 16.2 & 13.5 & 15.8 & 16.0 & 15.47 \\
\hline 75 percentile & 19.9 & 25.6 & 23.4 & 20.7 & 20.9 & 23.7 & 22.21 \\
\hline below $10 \mu \mathrm{g} / 100 \mu \mathrm{l}(\%)$ & 6.7 & 0 & 4.2 & 5.3 & 0 & 0 & 2.45 \\
\hline
\end{tabular}

Table of NCHS was used as standard reference.

$\mathrm{N}$ = number of children

* ANOVA $(p>0.05)$

** Kruskal-Wallis test $(p>0.05)$ 

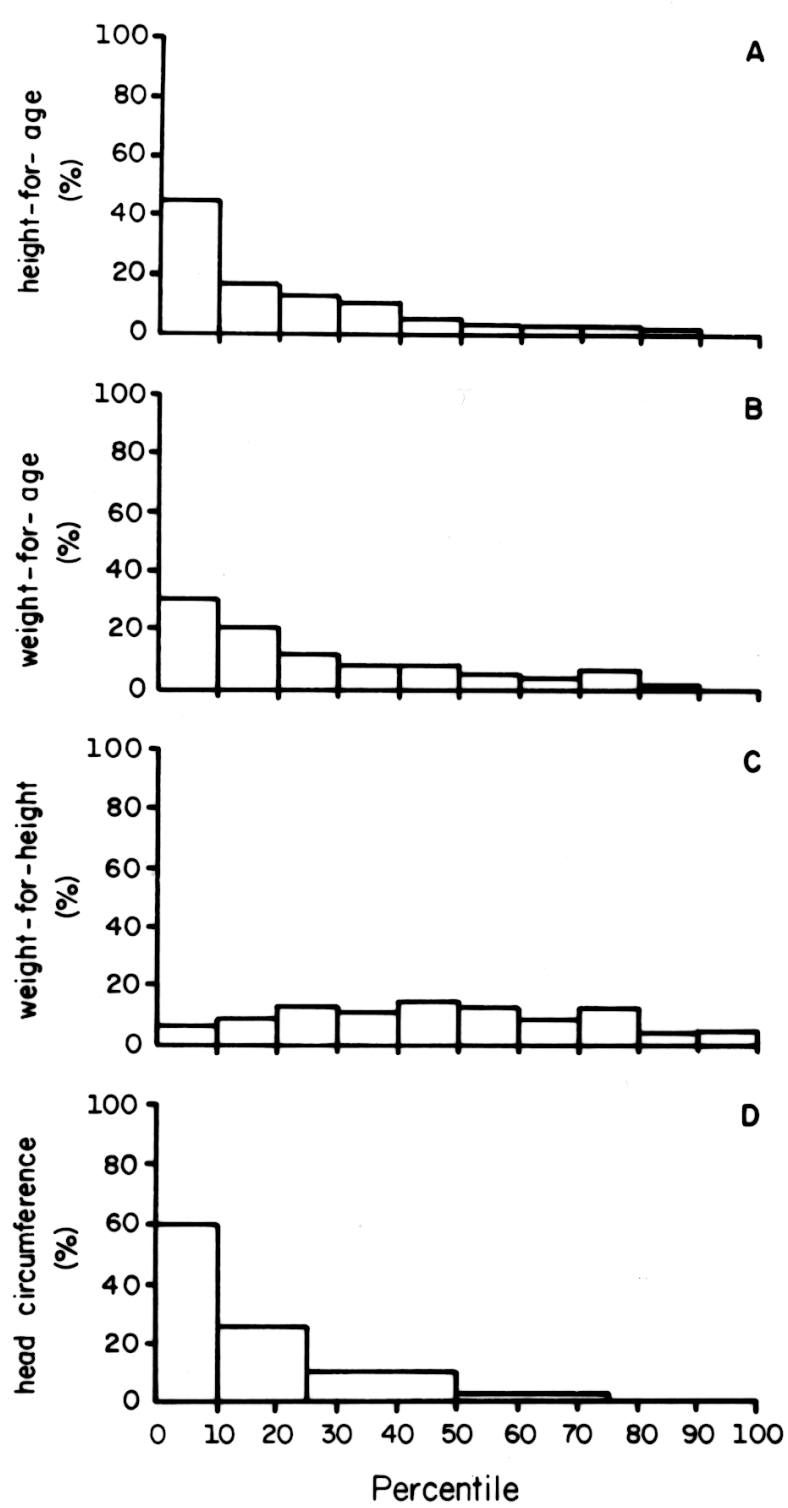

- Figure 1 - Distribution in percentiles of $A)$ height-for-age $(n=124)$, $B)$ weight-for-age $(n=124)$. C) weight-for-height $(n=124)$ and $D)$ head circumference $(n=68$ ) for children younger than 6 years old, living in Varjão, a slum area in Brasilia, Brazil. Growth charts of National Center for Health Statistic, USA, were used as the of National Center
normal standard.

The predominant diet of these children was rice and beans. Sixty eight percent (60/88) of the children ingested less than $80 \%$ of daily recommended intake of energy, while $61 \%(54 / 88)$ of them had an intake of more than $100 \%$ daily recommended intake in protein.

Anemia (hemoglobin concentration below $11 \mathrm{~g} / \mathrm{dL}$ ) was detected in $16.5 \%(20 / 121)$ of the children, all younger than 30 months of age. In $12.4 \%$ (15/121) of the children, hemoglobin concentration was between 10 $11 \mathrm{~g} / \mathrm{dL}$, and in $4.1 \%(5 / 121)$, it was between $7-10 \mathrm{~g} / \mathrm{dL}$.
The lowest hemoglobin concentration was found in children aged between 6 months and 1.5 years $(p<0.001$, ANOVA) (Figure 2).

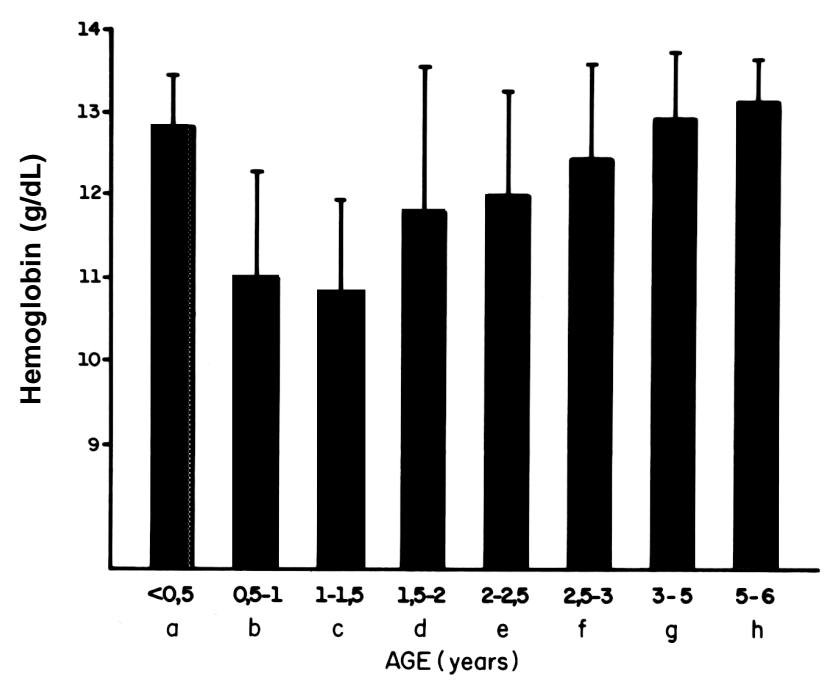

Figure 2 - Mean concentration of hemoglobin ( $\mathrm{g} / \mathrm{dL}$ ) of 121 children living in Varjão, Brasilia, Brazil, distributed by age. The children were distributed by ages in the following groups: a) $0-0.5$ years old $(n=5) ; b)>0.5$ - 1 years old $(n=10) ; c)>1-1.5$ years old $(n=12)$ : d) $>1.5-2$ years old $(n=14) ; e)>2-2.5$ years old $(n=11) ; f)>2.5$

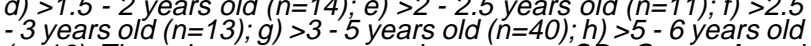
-3 years old $(n=13) ; g)>3-5$ years old $(n=40) ; h)>5-6$ years old
$(n=16)$. The values are expressed as mean \pm S $D$. Groups $b$ and $\boldsymbol{d}$ are statistically different from groups $\boldsymbol{g}$ and $\boldsymbol{h}$, and Group $\boldsymbol{c}$ is different from Groups $\boldsymbol{a}, \boldsymbol{f}, \boldsymbol{g}$ and $\boldsymbol{h}(p<0.001$, one way ANOVA and subsequent Student-Newman-Keuls method for multiple comparisons).

Fifty percent $(10 / 20)$ of children with hemoglobin concentration below $11 \mathrm{~g} / \mathrm{dL}$ had Ascaris lumbricoides, 25\% (5/20) Giardia lamblia, 15\% (3/20) Hymenolepis nana, 20\% (4/20) were polyparasitized, and 30\% (6/20) had no intestinal parasites. Prevalence of parasitic infection in 27 children with the same age (below 30 months old) and with hemoglobin concentration $\geq 11 \mathrm{~g} / \mathrm{dL}$ were: $33.3 \%$ (9/27) for Ascaris lumbricoides-infected, $25.9 \%$ (7/27) for Giardia lamblia, 7.4\% (2/27) for multiple parasites, while $48.15 \%$ (13/27) had no parasite. No difference was found in the mean concentration of serum retinol and the anthropometric indices in the groups with normal $(\geq 11 \mathrm{~g} / \mathrm{dL})$ and low $(<11 \mathrm{~g} / \mathrm{dL})$ hemoglobin concentrations.

Iron intake was below $80 \%$ daily recommended intake in 68 out of $88(77 \%)$ children. In 11 out of 12 $(91 \%)$ children with hemoglobin concentration below $11 \mathrm{~g} / \mathrm{dL}$ and that received no human milk, the daily recommended intake of iron was lower than $60 \%$.

Parasites were present in the stools of $75.5 \%$ (77/ 102 ) of the examined children (Table 2). Ascaris lumbricoides was the most prevalent parasite, being present in 47\% (48/102) of the children. The estimated load of Ascaris lumbricoides varied from 2 to 114 worms, $56.3 \%(27 / 48)$ of the children showing a light burden, $27.1 \%(13 / 48)$ a moderate one, and $16.7 \%(8 / 48)$ a 
Table 2 - Prevalence according to age of parasites in stool of children younger than 6 years old living in Varjão, a slum area in Brasilia, Brazil.

\begin{tabular}{|c|c|c|c|c|c|c|c|c|c|c|c|c|c|c|}
\hline \multirow[b]{4}{*}{ Parasite } & \multicolumn{11}{|c|}{ Frequency } & & & \\
\hline & \multicolumn{14}{|c|}{ age } \\
\hline & \multicolumn{2}{|c|}{$<1 \mathrm{y}$} & \multicolumn{2}{|c|}{$1-2 y$} & \multicolumn{2}{|c|}{$2-3 y$} & \multicolumn{2}{|c|}{$3-4 y$} & \multicolumn{2}{|c|}{$4-5 y$} & \multicolumn{2}{|c|}{$5-6 y$} & \multicolumn{2}{|c|}{ total } \\
\hline & $\mathrm{n}$ & $\%$ & $\mathrm{n}$ & $\%$ & $\mathrm{n}$ & $\%$ & $\mathrm{n}$ & $\%$ & $\mathrm{n}$ & $\%$ & $\mathrm{n}$ & $\%$ & $\mathrm{n}$ & $\%$ \\
\hline Absent & $7 / 11$ & 63.6 & $9 / 22$ & 40.9 & $4 / 21$ & 19.0 & $2 / 19$ & 10.5 & $4 / 18$ & 22.0 & $1 / 11$ & 9.1 & $27 / 102$ & 26.5 \\
\hline A. lumbricoides & $3 / 11$ & 27.3 & $9 / 22$ & 40.9 & $10 / 21$ & 47.6 & $12 / 19$ & 63.2 & $8 / 18$ & 44.5 & $6 / 11$ & 54.5 & $48 / 102$ & 47.0 \\
\hline G. lamblia & $1 / 11$ & 9.1 & $6 / 22$ & 27.3 & $6 / 21$ & 28.6 & $7 / 19$ & 36.8 & $6 / 18$ & 33.3 & $5 / 11$ & 45.5 & $31 / 102$ & 30.4 \\
\hline H. nana & $1 / 11$ & 9.1 & $1 / 22$ & 4.5 & $3 / 21$ & 14.3 & $7 / 19$ & 36.8 & $7 / 18$ & 38.9 & $3 / 11$ & 27.3 & $21 / 102$ & 20.6 \\
\hline T. trichiuris & $0 / 11$ & 0 & $0 / 22$ & 0 & $2 / 21$ & 9.5 & $4 / 19$ & 21.0 & $0 / 18$ & 0 & $1 / 11$ & 9.1 & $7 / 102$ & 6.9 \\
\hline S. stercoralis & $0 / 11$ & 0 & $0 / 22$ & 0 & $0 / 21$ & 0 & $0 / 19$ & 0 & $0 / 18$ & 0 & $1 / 11$ & 9.1 & $1 / 102$ & 0.98 \\
\hline$>1$ parasite & $1 / 11$ & 9.1 & $3 / 22$ & 13.6 & $4 / 21$ & 19.1 & $10 / 19$ & 52.6 & $6 / 18$ & 33.3 & $6 / 11$ & 54.5 & $30 / 102$ & 29.4 \\
\hline
\end{tabular}

A. lumbricoides = Ascaris lumbricoides; G. lamblia = Giardia lamblia;

$H$. nana = Hymenolepis nana; $T$. trichiuris = Trichuris trichiuris

S. stercoralis $=$ Strongyloides stercoralis

$y=$ years

heavy burden of Ascaris lumbricoides. There was no difference in the mean \pm SD of weight-for-age Z-score in children with light $(-0.76 \pm 0.98)$, moderate $(-0.60 \pm$ $0.82)$ or heavy $(-0.74 \pm 0.44)$ burden of Ascaris lumbricoides ( $p>0.05$, ANOVA), and no correlation was found between the age and the burden of Ascaris lumbricoides ( $\mathrm{p}>0.05$, Spearman correlation). Eggs of Ascaris lumbricoides and Hymenolepis nana were detected in children from 9 months old onwards, and cysts of Giardia lamblia from 11 months old. The prevalence of intestinal parasites according to children's age is shown in Table 2. Cysts of Giardia lamblia were also highly prevalent, with $30.4 \%$ (31/102) of the children infected. In $29.4 \%(30 / 102)$ of the subjects more than one parasite were observed (Table 2). The percentage of parasitized children below -2 SD Zscore for weight-for-age, weight-for-height and heightfor-age is showed in Table 3.

Table 3 - Percentage of children younger than 6 years old living in Varjão with weight-for-age, height-for-age and weight-for-height <-2 SD Z- score according to parasitic infection.

\begin{tabular}{lrrrrrr}
\hline & \multicolumn{7}{c}{ Children below -2 SD Z-score (\%) } \\
\cline { 2 - 7 } & \multicolumn{2}{c}{ weight-for-age } & \multicolumn{2}{c}{ height-for-age } & weight-for-height \\
\hline Non-infected & $11.1 \%$ & $3 / 27$ & $22.2 \%$ & $6 / 27$ & $0 \%$ & $0 / 27$ \\
Only A. lumbricoides & $8.7 \%$ & $2 / 23$ & $21.7 \%$ & $5 / 23$ & $0 \%$ & $0 / 23$ \\
Only G. lamblia & $25 \%$ & $3 / 12$ & $16.6 \%$ & $2 / 12$ & $8.3 \%$ & $1 / 12$ \\
Only H. nana & $0 \%$ & $0 / 8$ & $12.5 \%$ & $1 / 8$ & $0 \%$ & $0 / 8$ \\
A lumbricoides + G. lamblia & $8.3 \%$ & $1 / 12$ & $16.6 \%$ & $2 / 12$ & $0 \%$ & $0 / 12$ \\
$>1$ parasite* & $0 \%$ & $0 / 18$ & $0 \%$ & $0 / 18$ & $0 \%$ & $0 / 18$ \\
\hline
\end{tabular}

A. lumbricoides = Ascaris lumbricoides; G. lamblia = Giardia lamblia;

H. nana = Hymenolepis nana; T. trichiuris = Trichuris trichiuris

S. stercoralis $=$ Strongyloides stercoralis

* $>1$ parasite except Ascaris lumbricoides + Giardia lamblia

Among the parasites detected, only Giardia lamblia influenced the weight-for-age and weight-for-height. Children infected exclusively with Giardia lamblia showed weight-for-age Z-score lower than that of children exclusively infected with Ascaris lumbricoides $(p<0.048$, ANOVA) (Figure 3A), and the weight-forheight Z-score were lower than that of non-infected children or those exclusively infected with Ascaris lumbricoides or Hymenolepis nana ( $p=0.03$, ANOVA) (Figure 3B). Children coinfected with Ascaris lumbricoides and Giardia lamblia were in an intermediate situation (Figure $3 \mathrm{~A}$ and $3 \mathrm{~B}$ ). Parasitic infections caused no change of height-for-age Z- score $(p>0.05$, ANOVA) (Figure 3C).
Only $36.9 \%(45 / 122)$ of the children showed normal serum retinol concentration $(>20 \mu \mathrm{g} / 100 \mathrm{ml})$, while $60.6 \%$ $(74 / 122)$ presented levels between $10-20 \mu \mathrm{g} / 100 \mathrm{ml}$, and $2.45 \%(3 / 122)$ below $10 \mu \mathrm{g} / 100 \mathrm{ml}$. There was no statistical difference in retinol concentration in serum in the different age-groups (Table 1). Sixty five out of 88 children $(74 \%)$ showed retinol equivalent intake below $80 \%$ of daily recommended intake.

Sixty out of 122 children (49.2\%) were suffering some mild infectious disease when evaluated, including skin infections, diarrhea, acute otitis or upper respiratory tract infections. Only three out of 124 children presented axillary temperature higher than $37.5^{\circ} \mathrm{C}$. The retinol concentration in children with infections $(18.3 \mu \mathrm{g} / 100 \mathrm{ml})$ 

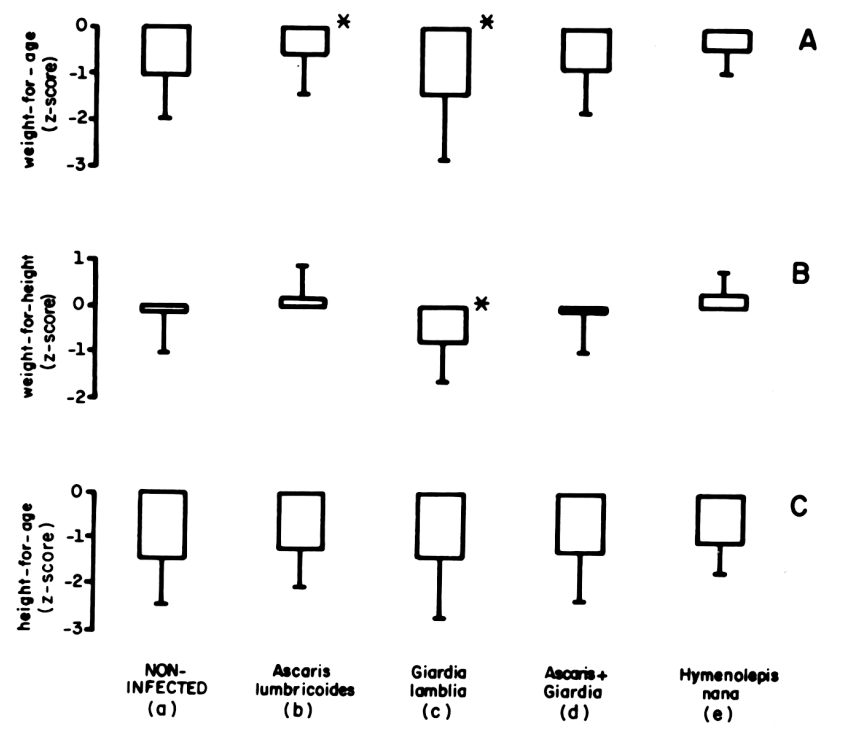

Figure 3 - Influence of intestinal parasitic infection on anthropometrical indices for $<6$ year-old-children, living in Varjão, Brasilia, Brazil. The children were distributed in the following groups: a) non-infected ( $n=27)$; b) infected exclusively by Ascaris lumbricoides ( $n=23)$; c) infected exclusively by Giardia lamblia $(n=12) ;$ d) coinfected by Ascaris lumbricoides and Giardia lamblia ( $n=12) ; \quad e$ ) infected exclusively by Hymenolepis nana $(n=8)$. The values are expressed as mean $\pm S D Z$-score. The $50^{\text {th }}$ percentile
of the growth charts of NCHS was used as the normal standard. In $\boldsymbol{A}$ : Weight-for-age. Group $\boldsymbol{b}$ is statistically different from Group In A: Weight-for-age. Group b is statistically different from Group
$c(p=0.04$, ANOVA and Student-Newman-Keuls method for multiple comparisons). In B: Weight-for-height. Group $c$ is statistically different from Groups $\boldsymbol{a}, \boldsymbol{b}$ and $\boldsymbol{e}(p=0.03$, ANOVA and Student-Newman-Keuls method for multiple comparisons). In C: Height-for-age. No statistical difference was observed between the Groups ( $p>0.05$, ANOVA).

were similar to that without infections $(18.2 \mu \mathrm{g} / 100 \mathrm{ml})$ ( $p>0.05$, Mann-Whitney test). Again, no difference in the serum retinol concentrations was detected among those infected with $(17.5 \mu \mathrm{g} / 100 \mathrm{ml})$ or without $(18.5 \mu \mathrm{g} / 100 \mathrm{ml})$ concomitant malnutrition, and also between wellnourished children with $(19.9 \mu \mathrm{g} / 100 \mathrm{ml})$ or without $(17.4 \mu \mathrm{g} / 100 \mathrm{ml})$ infection ( $p>0.05$, Kruskal-Wallis test).

Although the wasted children (weight-for-age Z-score <-2 SD) had lesser retinol in serum (median $=14.9 \mu \mathrm{g} / 100 \mathrm{ml}$ ) than the better nourished children $(>-2 S D)$ (median $=17.1 \mu \mathrm{g} / 100 \mathrm{ml} ; 19.5 \mu \mathrm{g} / 100 \mathrm{ml}$; $18.3 \mu \mathrm{g} / 100 \mathrm{ml})$ these differences were not statistically significant ( $p>0.05$, Kruskal Wallis test) (Figure 4A). A higher percentage of wasted children $(75 \% ; 9 / 12)$ showed retinol in serum below $20 \mu \mathrm{g} / 100 \mathrm{ml}$ than the better nourished children $(59 \%, 65 / 110)$, although also without statistical significance (Figure 4B).

Children exclusively infected by Hymenolepis nana showed serum retinol levels higher than those infected with other parasites ( $p=0.02$, Kruskal-Wallis test) (Figure 5A). No one child infected with Hymenolepis nana had weight-for-age below -2 SD Z-score (Figure 5B).

Both Ascaris lumbricoides-infected or non-infected wasted children (<-2 SD Z-score) showed low serum

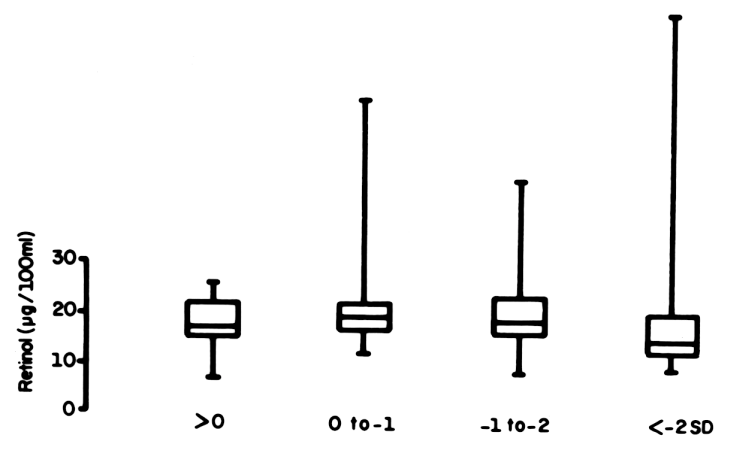

A

$$
\left.\begin{array}{cc} 
& 60 \\
\vdots & 40 \\
\vdots & 40 \\
\vdots & 20 \\
\vdots & 20 \\
\vdots & 10
\end{array}\right]
$$

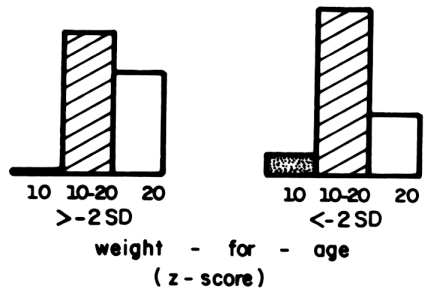

B

Figure 4 - Relationship between serum levels of vitamin $A$ and weightfor-age $Z$-score. In A: serum retinol concentration $(\mu \mathrm{g} / 100 \mathrm{ml})$ for children with median of weight-for-age Z-score $>0$, 0 to $-1,-1$ to -2 , $<-2 S D\left(50^{\text {th }}\right.$ percentile of the growth charts of NCHS was used as normal standard). The values are expressed as median, quartiles and extremes. ( $>0.05$, Kruskal-Wallis test). In B: percentage of children with the weight-for-age Z-score $\geq-2$ SD or lesser than $<-2 S D$ showing serum retinol concentration $\leq 10 \mu \mathrm{g} / 100 \mathrm{ml}, 10-20$ and $>20 \mu \mathrm{g} / 100 \mathrm{ml}$. There was no difference statistically significant between the groups ( $p>0.05$, Chi-square test).
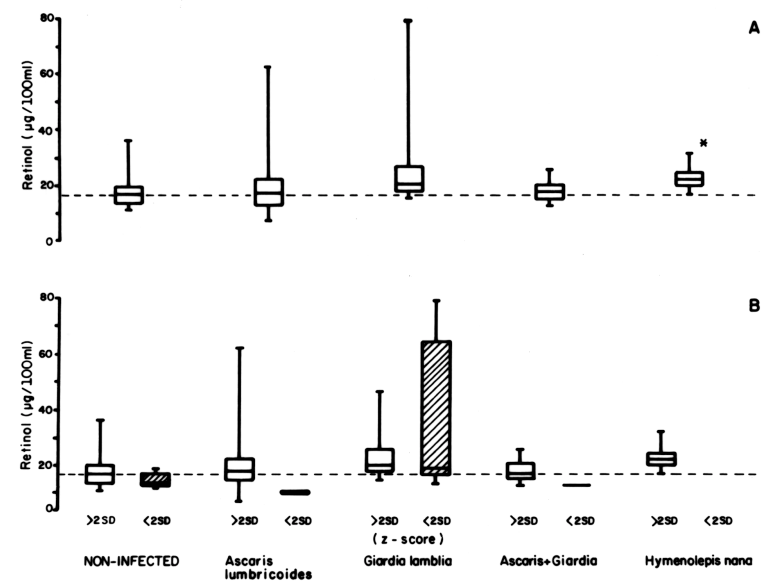

Figure 5 - Relationship between serum levels of vitamin A, parasitic intections and weight-for-age. In A: serum retinol concentration $(\mu \mathrm{g} /$ Ascaris lumbricoides (n=22), c) infected exclusively by Giardia lamblia $(n=11), d)$ coinfected by Ascaris lumbricoides and Giardia lamblia $(n=12)$ $e$ infected exclusively by Hymenolepis nana $(n=8)$ ( $p=0.028$, KruskalWallis test). The values are expressed as median, quartiles and extremes. In B: serum retinol concentration ( $\mu \mathrm{g} / 100 \mathrm{ml})$ in children: a) non-infected and distributed for $>-2$ or $<-2$ weight-for-age Z-score, b) infected exclusively with Ascaris lumbricoides and distributed for $>-2$ or $<-2$ weight-for-age Z-score, c) infected exclusively by Giardia lamblia and distributed for $>-2$ or <-2 weight-for-age Z-score, d) coinfected by Ascaris lumbricoides and Giardia lamblia and distributed for $>-2$ or $<-2$ weight for-age Z-score, e) infected exclusively by $H y m$ mopis nana and distributed for $>-2$ or $<-2$ weight-for-age Z-score. The $50^{\text {th }}$ percentile
of the growth charts of NCHS, USA, was used as the normal standard. 
retinol concentrations (Figure 5B). However, the wasted children (<-2 SD Z-score) infected with Ascaris lumbricoides had the lowest value of serum retinol concentration (Figure 5B).

\section{DISCUSSION}

The group of children studied showed a high prevalence of protein-energy malnutrition, hypovitaminosis $A$ and intestinal parasitic infections. The head circumference and the height-for-age were the most altered anthropometric indices. However, these children showed a normal weight-for-height, suggesting an adaptation to the chronic nutritional deficit. Children under one year of age showed a higher deficit in weightfor-age and height-for-age than older children, with $20 \%$ and $40 \%$, respectively, below - 2 SD Z-score.

Two major consequences may result from proteinenergy malnutrition: deficient physical growth and intellectual performance. Wachs ${ }^{40}$ suggested that chronic, mild postnatal malnutrition might be associated with a variety of cognitive and behavioral deficits across the life span. However, malnutrition appears to be a necessary but not a sufficient condition for causing behavioral deficits ${ }^{40}$. Waterlow ${ }^{42}$ considers that the consequences for intellectual development of the nonsevere lower physical growth and the lower head circumference, related to the international growth charts of NCHS, as observed in our Brazilian children, are not yet clarified ${ }^{42}$. However, it has been recognized that the risk of a child dying is increased when infection is associated to malnutrition, even a mild one ${ }^{33} 36$.

Anemia detected by laboratory test was present in $17 \%$ of the children and was possibly due to the low iron intake. This occurred mainly in the age group between 6 months and 2.5 years old. This is when the predominance of cow's milk intake (poor in iron) in diet may led to low iron intake ${ }^{3}$. In fact, we detected a low iron intake in $91 \%$ of these anemic children. In $78 \%$ of the whole group, iron intake was deficient. The possibility that the iron stores of these children were depleted cannot be excluded.

Parasites were present in $75.5 \%$ of the children, and $29.4 \%$ of them were infected by multiple parasites. Ascaris lumbricoides and Giardia lamblia were the two most prevalent parasites observed in our study population. Eggs of Ancilostomidae were not observed and anemia was not a major problem in these children. However, it is possible that these parasites were not found because we studied only children under 6 years old, and Ancylostomidae are mostly prevalent in adult workers ${ }^{6}$. Eggs of Ascaris lumbricoides and Hymenolepis nana were present in children as young as 9 months suggesting a low degree of sanitation and education in this population.

The pathologic consequences of multiple parasitic infections for the host and its metabolic cost are unknown. It has been suggested that the interactions between parasites in the host may have either antagonistic or synergistic effects, and can result in worsening of inflammatory reactions and clinical manifestations to the parasites ${ }^{26}$. In our study, only
Giardia lamblia infection was related to deleterious consequences to protein-energy nutritional status. Giardia lamblia-infected children had significantly decreased weight-for-age and weight-for-height, while these anthropometric indices were not negatively affected in children infected with Ascaris lumbricoides and Hymenolepis nana. Children coinfected by Ascaris lumbricoides and Giardia lamblia were in an intermediate situation between the children infected exclusively by Giardia lamblia or Ascaris lumbricoides, in relation to protein-energy nutrition. This finding suggests an antagonistic effect between these two parasites. Whether the infection by Giardia lamblia was acute or chronic may also have influenced the end result.

Ascaris lumbricoides- or Hymenolepis nana-infected children presented weight-for-age and height-for-weight higher than the non-infected. It is recognized that the level of adult helminth infection in an individual host is determined by the balance between establishment of the parasites (input) and their death (output) ${ }^{6}$. The input depends mainly on public health sanitation and educational level, while output depends on the factors associated to the parasite and/or host. For the worm intestinal expulsion to occur, an environment must be created that is too hostile for juvenile and adult worms to continue to develop, or maintain their position ${ }^{8}$. Thus, it is a possibility that, in well-nourished children the abundance of food and the favorable microenvironment around the parasite in the intestinal environment facilitates maintenance of the established parasite for a longer time. Another possibility is that some specific nutrient may be necessary for parasite survival.

The children under study showed predominantly mild or moderate protein-energy malnutrition, and only $14.5 \%$ of them presented a heavy load of Ascaris lumbricoides. Malnutrition was not a problem in helminth-infected children; on the contrary, these children were better nourished. This fact may suggest a minor influence of infection by intestinal helminthes on the nutrition and growth of the children when they have a low burden of parasite and mild malnutrition. It is possible to conclude that light or moderate parasitism with Ascaris lumbricoides did not cause a major detrimental effect on the nutritional status of the children, but it is possible that a heavy burden of the parasite in children also with a deficit in food supply can do so. Furthermore, it is not possible to determine whether these better nourished children would have been heavier and taller if they had grown without parasitic infections. Neither helminth nor Giardia lamblia infection influenced the height-for-age. This fact suggests that parasites had only a short and temporary influence on the children's growth.

The group younger than 1 year old presented a low frequency of parasite infection but showed a higher 
percentage of protein-energy malnutrition. The reasons why these non parasite-infected children had low antrophometric indices and vitamin A serum levels were not clarified. It is possible that in the first year of the life the children may be more susceptible to other negative outside influences independent of parasite infections.

The concomitant infections by viruses and bacteria in the group investigated need to be analyzed. Most infections, including those responsible for mild diarrhea and respiratory diseases, provoke an acute-phase reaction which reduces the synthesis of retinol-binding protein in the liver, and so depresses circulating retinol. This fact does not imply reduced overall vitamin $A$ stores, but may result in a temporary impairment of transport of vitamin A to functional locations ${ }^{4}$. Infectious diseases apparently were not the main cause of the lower values of retinol observed in these children. However, we cannot rule out the possibility that the level of retinol in such infected-children would be higher if they were non-infected.

Hypovitaminosis A was a major nutritional deficiency in this population under investigation. The main sources of vitamin A are milk, meat, liver, fish, eggs, green vegetables and some orange colored fruits and vegetables ${ }^{29}$, besides, it is fat-soluble and depends on lipids for intestinal absorption ${ }^{24}$, and these kinds of food are not cheap. Considering the low vitamin A intake, the absence of relation from retinol with parasitoses, and the absence of relationship between retinol and infectious diseases, it appears that the low food intake was the main cause of this deficiency. Besides, children below -2 SD weight-for-age Z-score also showed the lowest level of serum retinol. It is possible that in these children the low supply, and poor variety of food, with predominance of rice and beans, had affected both protein-energy nutritional status and vitamin A status. It is not clear why children infected by Hymenolepis nana showed values of retinol higher than the other groups.

Our data indicate that malnutrition is more importantly affected by socio- economical and cultural factors, capable of impairing food supply and intake, than by metabolic cost of parasitism and the impairment in digestion and absorption by intestinal parasitic infections, except for Giardia lamblia. This latter parasite apparently facilitated the development of protein-energy malnutrition. However, it is likely that helminth infection is not detrimental to nutritional state, provided that food intake is adequate. The association of both low food intake and parasite infections was detrimental.

Our data support the hypothesis that early treatment of Giardia lamblia infection will improve the growth of infected children. We need to treat helminth diseases to decrease the morbidity and mortality of related illnesses. However, treatment of helminthes alone would not be efficient as a measure to improve growth of children since these children were no more malnourished than non-parasitized children before treatment. Strategies to increase the supply and intake of food would probably be more effective in poor populations.

\section{ACKNOWLEDGEMENTS}

The authors extend their thanks Prof. Dr. Carlos Eduardo Tosta and Prof. Dr. Marina Ito for reviewing the manuscript, Mr. Werte de Souza Chaves for technical assistance and Mr. Paulo Hipólito Bezerra Leite and Mr. José Cals da Rocha for preparing the figures.

\section{REFERENCES}

1. Adam RD. The biology of Giardia spp. Microbiological Reviews 55, 706-732, 1991.

2. Anonymous. Ascariasis, giardiasis and growth. Nutrition Reviews 41: 149-151, 1983.

3. Baker SJ, DeMaeyer EM. Nutritional anemia: its understanding and control with special reference to the work of the World Health Organization. The American Journal of Clinical Nutrition 32: 368417, 1979.

4. Bates CJ. Vitamin A. The Lancet 345: 31-35, 1995.

5. Bradley DW, Hornbeck CL. A clinical evaluation of an improved TFA micromethod for plasma and serum vitamin A. Biochemical Medicine 7: 78-86, 1973.

6. Bundy DAP, Medley GF. Immuno-epidemiology of human geohelminthiasis: ecological and immunological determinants of worm burden. Parasitology 104: S105-S119, 1992.

7. Cerf BJ, Rohde JE, Soesanto T. Ascaris and malnutrition in a Balinese village: a conditional relationship. Tropical and Geographical Medicine 33: 367-373, 1981.

8. Cooper ES, Whyte-Alleng CAM, Finzi-Smith JS, MacDonald TT. Intestinal nematode infections in children: the pathophysiological price paid. Parasitology 104: S91-S103, 1992.
9. Crompton DWT. Influence of parasitic infection on food intake. Federation Proceedings 43: 239-245, 1984.

10. Crompton DWT. Nutritional aspects of infection. Transactions of the Royal Society of Tropical Medicine and Hygiene 80: 697-705, 1986.

11. Davidsohn I, Nelson DA. The blood. In: Davidsohn I, Henry J B (ed) Clinical diagnosis by laboratory methods, $16^{\text {th }}$ edition, Saunders, Phyladelphia, p. 120-330, 1969.

12. Food and Agriculture Organization of the United Nations (FAO)/ World Health Organization. Requirements of vitamin A, thiamine, riboflavine and niacin. Report of a joint FAO/WHO expert group. World Health Organization Technical Report Series 362, 1967.

13. Food and Agriculture Organization of the United Nations (FAO)/ World Health Organization. Requirements of ascorbic acid, vitamin $\mathrm{D}$, vitamin B12, folate and iron. Report of a joint FAO/WHO expert group. World Health Organization Technical Report Series 452, 1970.

14. Food and Agriculture Organization of the United Nations (FAO)/ World Health Organization. Necesidades de energía y de proteínas. Informe de una Reunión Consultiva Conjunta FAO/OMS/UNU de Expertos. Organización Mundial de la Salud. Serie de Informes Técnicos 724, 1985. 
15. Freij L, Meeuwisse GW, Berg NO, Wall S, Gebre-Medhin M Ascariasis and malnutrition. A study in urban Ethiopian children. The American Journal of Clinical Nutrition 32: 1545-1553, 1979.

16. Glikman LT, Chaudry HU, Costantino J, Clack FB, Cypess R H, Winslow L. Pica patterns, toxocariasis, and elevated blood lead in children. The American Journal of Tropical Medicine and Hygiene 30: 77-80, 1981.

17. Greenberg BL, Gilman RH, Shapiro H, Gilman JB, Mondal G, Maksud M, Khatoon H, Chowdhury J. Single dose piperazine therapy for Ascaris lumbricoides: an unsuccessful method of promoting growth. The American Journal of Clinical Nutrition 34: 2508-2516, 1981.

18. Gupta MC, Mithal S, Arora KL, Tandon BN. Effect of periodic deworming on nutritional status of Ascaris-infested preschool children receiving supplementary food. The Lancet 16: 108-110, 1977.

19. Gupta MC, Urrutia JJ. Effect of periodic antiascaris and antigiardia treatment on nutritional status of preschool children. The American Journal of Clinical Nutrition 36: 79-86, 1982.

20. Hall A. Intestinal parasitic worms and the growth of children. Transactions of the Royal Society of Tropical Medicine and Hygiene 87: 241-242, 1993.

21. Hamill PVV, Drizd TA, Johnson CL, Reed RB, Roche AF, Moore WM. Physical growth: National Center for Health Statistics percentiles. The American Journal of Clinical Nutrition 32: 607-629, 1979.

22. Hlaing T. Ascariasis and childhood malnutrition. Parasitology 107 : S125-136, 1993.

23. Instituto Brasilleiro de Geografia e Estastística. Tabela de composição de alimentos. ENDEF. Fundação Instituto Brasileiro de Geografia e Estatística, 1977.

24. Jalal F, Nesheim MC, Agus Z, Sanjur D, Habicht JP. Serum retinol concentrations in children are affected by food sources of $\beta$ carotene, fat intake, and anthelminthic drug treatment. The American Journal of Nutrition 68: 623-629, 1998.

25. Katz N, Chaves A, Pellegrino J. A simple device for quantitative stool thick-smear technique in Schistosomiasis mansoni. Revista do Instituto de Medicina Tropical de São Paulo 14:397-400, 1972.

26. Keusch GT, Migasena P. Biological implications of polyparasitism. Reviews of Infectious Diseases 4: 880-882, 1982.

27. Kightlinger LK, Seed JR, Kightlinger MB. Ascaris lumbricoides aggregation in relation to child growth status, delayed cutaneous hypersensitivity, and plant anthelminthic use in Madagascar. Journal of Parasitology 82: 25-33, 1996.

28. Mahalanabis D, Simpson TW, Chakraborty ML, Ganguli C, Bhattacharjee AK, Mukherjee KL. Malabsorption of water miscible vitamin $\mathrm{A}$ in children with giardiasis and ascariasis. The American Journal of Clinical Nutrition 32: 313-318, 1979.

29. Nesheim MC. Human nutrition needs and parasitic infections. Parasitology 107: S7-18, 1993.

30. Olson JA. The irresistible fascination of carotenoids and vitamin A. The American Journal of Clinical Nutrition 57: 833-839, 1993.
31. Persson V, Ahmed F, Gebre-Medhin M, Greiner T. Relationships between vitamin A, iron status and helminthiasis in Bangladeshi school children. Public Health Nutrition 3: 83-89, 2000.

32. Pessôa SB. Noções de técnica parasitológica. In: Pessôa S B (ed) Parasitologia Médica, 7a edição, Guanabara Koogan, Rio de Janeiro p. 865-908, 1969.

33. Puffer RR, Serrano CV. Caracteristicas de la mortalidade en la niñez. Organizacion Pan-Americana de la Salud. Publicacion Cientifica $\mathrm{n}^{\circ}$ 262, 1973.

34. Roche M, Layrisse M. Nature and causes of hookworm anaemia. The American Journal of Tropical Medicine and Hygiene 15: 10321098, 1966.

35. Rosenberg IH, Bowman BB. Impact of intestinal parasites on digestive function in humans. Federation Proceedings 43: 246250, 1984.

36. Schroeder DG, Brown KH. Nutritional status as a predictor of child survival: summarizing the association and quantifying its global impact. Bulletin of the World Health Organization 72:569-579, 1994.

37. Stephenson LS, Crompton DWT, Latham MC, Schulpen TWJ, Nesheim MC, Jansen AAJ. Relationships between Ascaris infection and growth of malnourished preschool children in Kenya. The American Journal of Clinical Nutrition 33: 1165-1172, 1980.

38. Stephenson LS, Latham MC, Kurz KM, Kinoti SN, Brigham H. Treatment with a single dose of albendazole improves growth of Kenyan schoolchildren with hookworm, Trichuris trichiura, and Ascaris lumbricoides infections. The American Journal of Tropical Medicine and Hygiene 41: 78-87, 1989.

39. Tripathy K, González F, Lotero H, Bolaños O. Effects of Ascaris infection on human nutrition. The American Journal of Tropical Medicine and Hygiene 20: 212-218, 1971.

40. Wachs TD. Relation of mild-to-moderate malnutrition to human development: correlational studies. The Journal of Nutrition 125: 2245S-2254S, 1995.

41. Waterlow JC. Classification and definition of protein-energy malnutrition. In: Beaton GH, Bengoa JM (eds) Nutrition in Preventive Medicine. World Health Organization. Monograph 62, 530-554, 1976.

42. Waterlow JC. Childhood malnutrition in developing nations: looking back and looking forward. Annual Review of Nutrition 14: 1-19, 1994.

43. Willett WC, Kilama WL, Kihamia CM. Ascaris and growth rates: a randomized trial of treatment. American Journal of Public Health 69: 987-991, 1979.

44. World Health Organization. Biomedical Research: a revised code of ethics. World Health Organization Chronicle 30:360-362, 1976.

45. World Health Organization. Field studies on the relation between intestinal parasitic infections and human nutrition. WHO/ NUT/ 81.3, PDP/82.4, 1-32, 1982.

46. World Health Organization. Physical status: the use and interpretation of anthropometry. World Health Organization Technical Report Series, 854, 1995. 